消化器内視鏡下治療におけるNd-YAGレーザー

\title{
の接触照射法について
}

\section{Contact Irradiation of Nd-YAG Laser in the Endoscopic Treatment of Digestive organs}

○. 加减秀樹, 过村大次郎, 松井洋勝

羽白清, 山本俊夫

Hideki Kagen, Dai jirou Tsujimura, Hiroktsu Matsui

Kiyoshi Hajiro, Toshio Yamamoto

近畿大学矤学部第 2 内科

The Second Department of Internal Medicine, University of Kinki

\begin{abstract}
Contact irradiation of $N d-Y A G$ laser was applied to bovine 1 iver, mouse transplantable colon 38 , and human gastric adenoma by a newly developed artificial sapphire probe, which is superior to quartz fiber is its heat resistance, hardness, and mechanical strength. The laser being applied to bovine 1 iver at variable energy and irradiation time, the relationship between energy and effectiveness was consequently found out to be determined more aculately in contact method. The differences in tissue coagulation between $\mathrm{CO}_{2}$ and distilled water used to protect the probe were also studied and concluded that adhesion of coagulated tissue could be prevented by allowing an outflow of distilled water and the abdominal distention relieved in the clinical treatment.
\end{abstract}

\section{I 緒 言}

近年 Nd-YAGレーザーによる消化器内視鏡下治 镜が活発に行われる様になったが，未だ解波す心゙ き問題点が種々指摘されている。従来の韭接触照 射の場合，照射距離を常に一定に保つととは不可 能である。乙のため照射エネルギーと効果の関係 が不明瞭となる。又非接触照射では，図1のごと く発散角度 $\Theta$, 距離 $\mathrm{d}$ における照射面の power densityは照射距㕍の 2 乗に反比例して減弱する。
われわれはこれらの問題を解決するために接触型 凝固端子を開発し基璴実験及び臨床応用を行い若 干の知兒を得たので報告する。

\section{II装置と対象・方法}

\section{1. 装置}

図 2 は新しく開発した接触型疑固端子のシェー マである。材質は酸化アルミニウ $ム\left(\mathrm{Al}_{2} \mathrm{O}_{3}\right)$ の溶 融体(人エサファイア)である。レーザー導光ファイ 


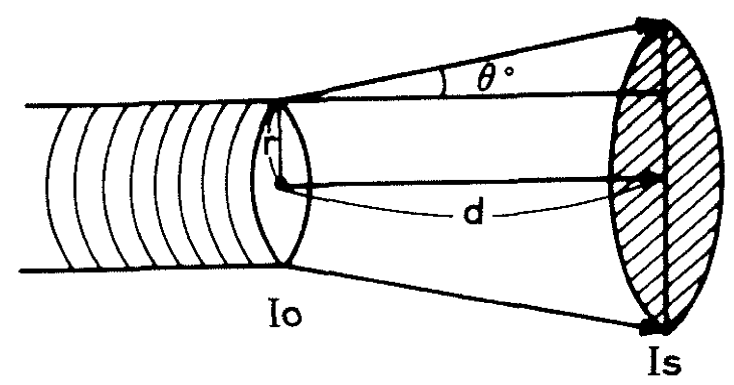

$$
\mathrm{Is}=\frac{\mathrm{Io}}{\pi(\mathrm{r}+\mathrm{dtan} \theta)^{2}}\left(\mathrm{~W} / \mathrm{cm}^{2}\right)
$$

汹 1 距離 $\mathrm{d}$, 発散角度 $\ominus$ における照射面の power density(Is). Io:照射エネルギー バーは従来通り石英を用いている。表 1 は人工サ ファイアを石英の特性の比較を示す。人工サファイ アは石英に比し耐熱温度・強度・硬度の点で優れ ている。てれらの事は直接組織に接触して照射し ても石英よりも破損しにくいととを示している。 レーザー発生装置はMBB製Medilas（Nd－YAG Laser)を使用した。

\section{2. 対象と方法}

照射エネルギーと効果の関係を観察するために 牛肝臟に対して接触照射した。照射条件は $10 \mathrm{~W}$ ， $15 \mathrm{~W}, 20 \mathrm{~W}$ でそれぞれに 1.0 秒から 3.0 秒まで変 えて照射し凝固径と深さを計測した。この際凝固 端子の保護のために使用する $\mathrm{CO}_{2}(400 \mathrm{ml} / \mathrm{min})$ と蒸 溜水 $(0.5 \mathrm{ml} / \mathrm{min})$ での組織凝固の差について比較 した。次に同装置を用いて生後 $4 \sim 6$ 週，体重 20 gのC57 BLACK 雌性マウスの腹壁下に c ol on38 を移植 4 週間後にエーテル麻酔下で $15 \mathrm{~W} \cdot 2.0$ 秒・ 20 回 total $600 \mathrm{~J}$ 照射した。

\section{III 結 果}

表 2 に示すように、照射エネルギーと凝固径・ 潹さの関係は, 出力・照射時間にほほ比例する。 凝固端子の保護のために $\mathrm{CO}_{2}(400 \mathrm{ml} / \mathrm{min})$ と蒸 溜水 $(0.5 \mathrm{ml} / \mathrm{min})$ を使用したが， $\mathrm{CO}_{2}$ を使用した 場合には $15 \mathrm{~W} \cdot 3.0$ 秒， $2.0 \mathrm{~W} \cdot 2.0$ 秒以上で組織 の蒸散が起った。蒸溜水を使用した場合には $15 \mathrm{~W}$ ・1.5秒以上, $20 \mathrm{~W} \cdot 1.0$ 秒以上で組織の蒸散が起

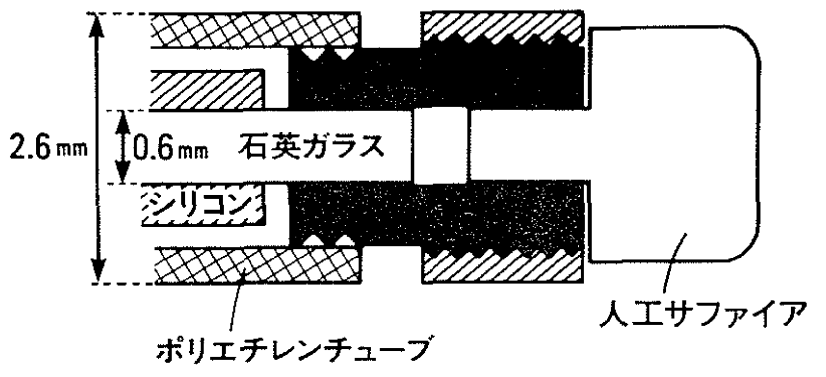

図 2 接触型凝固端子の構造

表 1 接触型凝固端子（人エサファイア）の特性

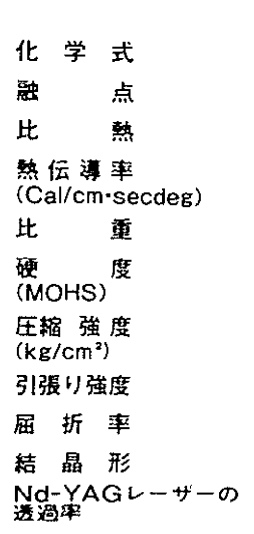

$\begin{array}{cc}\frac{\text { \#ファイア }}{\mathrm{Al}_{2} \mathrm{O}_{3}} & \frac{\text { 百英 }}{\mathrm{SiO}_{2}} \\ 2030 \sim 2050^{\circ} \mathrm{C} & 1600^{\circ} \mathrm{C} \\ 0.18(25 \mathrm{C}) & 0.17\left(25^{\circ} \mathrm{C}\right) \\ 0.0016 \sim 0.0034 & 0.0158 \sim 0.0299 \\ (40 \mathrm{C}) & \left(40^{\circ} \mathrm{C}\right) \\ 4.0 & 2.2 \\ 9 & 7 \\ 28000 & 20000 \\ 2000 & 900 \sim 1200 \\ 1.76 & 1.54 \\ \text { 六方晶系 } & \text { 六方晶系 } \\ >90 \% & >90 \%\end{array}$

った。又 $15 \mathrm{~W} \cdot 3.0$ 秒, $20 \mathrm{~W} \cdot 2.0$ 秒以上の照射 では疑固はかなり大きく不整形となるため計測は 省略した。 $\mathrm{CO}_{2}$ と蒸溜水を使用した結果を比較卞 ると，凝固径は蒸溜水を使用した方が，又疑固の 深さは $\mathrm{CO}_{2}$ を使用した方が大きくなる傾向を示し た。（凝固径はすべての条件で，深さは $15 \mathrm{~W}, 20$ Wの条件で $\mathrm{P}<0.01$ 亿扔いて有意差が認められ た。）凝固組織の凝固端子への付着は $\mathrm{CO}_{2}$ では見 られたが、蒸溜水の場合にはなかった。又臨床に 応用した際には，患者の腹满感を軽減できた。表 $3 \mathrm{KCO}_{2}$ と蒸溜水を使用した際の比較を示す。

Colon38に対して接触照射した結果，1週間後 に腫燩は消失し照射部は痩痕となり 5 ケ月後の現 在再発はない。 
表 2 牛肝臟に対する $\mathrm{Nd}-\mathrm{YAG} レ$ ーザー接触照 射による凝固径と深さの計測 (単位は $m m$ )

蒸溜水 $(0.5 \mathrm{ml} / \mathrm{min})$

\begin{tabular}{|c|c|c|c|}
\hline sec. $w$ & 10 & 15 & 20 \\
\hline 1.0 & $\begin{array}{l}0.97 \\
0.46\end{array}$ & $\begin{array}{l}3.05 \\
0.57\end{array}$ & $\begin{array}{l}3.43 \\
(1.08) \\
0.95 \\
(0.41)\end{array}$ \\
\hline 1.5 & $\begin{array}{l}2.57 \\
0.59\end{array}$ & $\begin{array}{l}4.11 \\
(1.05) \\
0.97 \\
(0.57)\end{array}$ & $\begin{array}{l}7.76 \\
(1.41) \\
1.03 \\
(0.41)\end{array}$ \\
\hline 2.0 & $\begin{array}{l}3.03 \\
0.73\end{array}$ & $\begin{array}{c}6.97 \\
(1.27) \\
1.35 \\
(0.65)\end{array}$ & \\
\hline 3.0 & $\begin{array}{l}3.81 \\
1.41\end{array}$ & & \\
\hline
\end{tabular}

表 $3 \mathrm{CO}_{2}(400 \mathrm{ml} / \mathrm{min})$ と蒸溜水 $(0.5 \mathrm{ml} / \mathrm{min})$ の 比較

\begin{tabular}{|c|c|c|c|c|}
\hline & 㩐固径 & $\begin{array}{l}\text { 政固の } \\
\text { 深 さ }\end{array}$ & 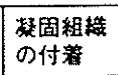 & 滕满感 \\
\hline $\begin{array}{l}\text { 蒸細 水 } \\
(0.5 \mathrm{~m} / \mathrm{min})\end{array}$ & 大 & 浅 & - & - \\
\hline $\begin{array}{c}\mathrm{CO}_{2} \\
(400 \mathrm{~m} / / \mathrm{min})\end{array}$ & 小 & 深 & + & + \\
\hline
\end{tabular}

IV 症 例

患者: 73歳, 男性。

主訴：胃部不快感。

既往歴：昭和55年左婜孟腫崲のため左腎摘出。 眧和56年膀胱霾滨のためTUR施行。

現病歴：昭和59年5月頃より胃部不快感出現。

嘔気・嘔吐や体重减少はなかった。同年6月12日 亿胃X線検査を受け幽門前庭部後壁に隆起性病変 を指摘され，内視鏡検查を受けた。その結果 gas tric adenoma と唁断されたためレーザー照射目 的にて当科入院した。

現症：体格は中等度で皮局・眼球結膜に黄染な く，表在性リンパ節触知せず，心肺に異常なし。 腹部は平坦で圧痛なし。肝・脾触知せず。浮腫は なし。
上段は直径，下段は深さを表わす

（ ）：蒸散による組織欠損

$\mathrm{CO}_{2}(400 \mathrm{ml} / \mathrm{min})$

\begin{tabular}{|c|c|c|c|}
\hline sec. $w$ & 10 & 15 & 20 \\
\hline \multirow{2}{*}{1.0} & 0.32 & 0.84 & 1.86 \\
& 0.46 & 0.90 & 1.38 \\
\hline \multirow{2}{*}{1.5} & 0.78 & 1.38 & 2.70 \\
& 0.80 & 1.58 & 2.00 \\
\hline \multirow{2}{*}{2.0} & 1.20 & 2.14 & $\begin{array}{c}3.48 \\
(1.90)\end{array}$ \\
& 1.14 & 1.94 & $\begin{array}{c}2.24 \\
(0.84)\end{array}$ \\
\hline \multirow{3}{*}{3.0} & 2.10 & $\begin{array}{c}3.38 \\
(1.90)\end{array}$ & $\begin{array}{c}3.84 \\
(2.22)\end{array}$ \\
& 1.40 & 2.52 & 2.62 \\
$(1.08)$ & $(1.34)$ \\
\hline
\end{tabular}

入院時検查成績 : 表 4 亿示すように軽度の貧血 を認めた。CEAは正常範囲であった。

胃X線検查: 背卧位二重造影 (図 3 ) 飞て削庭 部後壁にバリウム斑にとり囲まれた表面凹凸な隆 起性病変が認められ，II 弪疑われた。

胃内視鏡検査 : 図 4-aに示すように前庭部に表 面軽度凹凸で乳白色調を呈する编平な隆起性病変 が認められた。同部の生検結果はgrouplli であっ た。そのため完全生検査目的にsnare polypectomy

表 4 入院時検查所見

\begin{tabular}{|c|c|c|c|}
\hline \multicolumn{2}{|l|}{ Urine } & LAP & 124 G.U \\
\hline \multicolumn{2}{|c|}{ glucose } & $\gamma$-GTP & $32 \mathrm{mU} / \mathrm{ml}$ \\
\hline \multirow{2}{*}{\multicolumn{2}{|c|}{ protein }} & Ch. E. & $0.87 \Delta \mathrm{pH}$ \\
\hline & & T. chol & $201 \mathrm{mg} / \mathrm{d} \ell$ \\
\hline \multicolumn{2}{|l|}{ Stool } & T. Bil & $0.6 \mathrm{mg} / \mathrm{d} \ell$ \\
\hline \multirow{2}{*}{\multicolumn{2}{|c|}{ occult blood }} & D. Bil & $0.2 \mathrm{mg} / \mathrm{d} \ell$ \\
\hline & & T. Protein & $7.4 \mathrm{~g} / \mathrm{d} \ell$ \\
\hline \multicolumn{2}{|c|}{ Peripheral blood } & albumin & $4.1 \mathrm{~g} / \mathrm{d} \ell$ \\
\hline RBC & $353 \times 10^{4} / \mathrm{mm}^{3}$ & $\mathrm{Na}$ & $140 \mathrm{mEq} / \mathrm{l}$ \\
\hline $\mathrm{Hb}$ & $12.9 \mathrm{~g} / \mathrm{d} \ell$ & K & $4.2 \mathrm{mEq} / \mathrm{l}$ \\
\hline $\mathrm{Ht}$ & $36.8 \%$ & $\mathrm{Cl}$ & $107 \mathrm{mEq} / \mathrm{\ell}$ \\
\hline WBC & $4900 / \mathrm{mm}^{3}$ & BUN & $21 \mathrm{mg} / \mathrm{d} \ell$ \\
\hline Plts & $14.9 \times 10^{4} / \mathrm{mm}^{3}$ & Creatinine & $1.0 \mathrm{mg} / \mathrm{d} \ell$ \\
\hline \multicolumn{2}{|c|}{ Blood chemistry } & ESR & $23 \mathrm{~mm} / \mathrm{hr}$ \\
\hline GOT & $14 \mathrm{U} / \mathrm{L}$ & & \\
\hline GPT & $13 \mathrm{U} / \mathrm{L}$ & CEA & $1.6 \mathrm{ng} / \mathrm{d} \mathrm{f}$ \\
\hline ALP & $98 \mathrm{U} / \mathrm{L}$ & & \\
\hline $\mathrm{LDH}$ & $132 \mathrm{U} / \mathrm{L}$ & & \\
\hline
\end{tabular}


施行 (図 4-b)した。摘出標本の病理診断は gastric adenomaであった。図4-bに示すように周 团に残存病変あるため $\mathrm{Nd}-\mathrm{YAG}$ - ーザーを計 975 J接触照射した。図 $4-\mathrm{c}$ は照射直後で病変部は 浮腫状になっている。図 4-d は照射 5 日後で残 存病変は完全に消失し同部は $\mathrm{A}_{2}$ の漬煌を形成した。

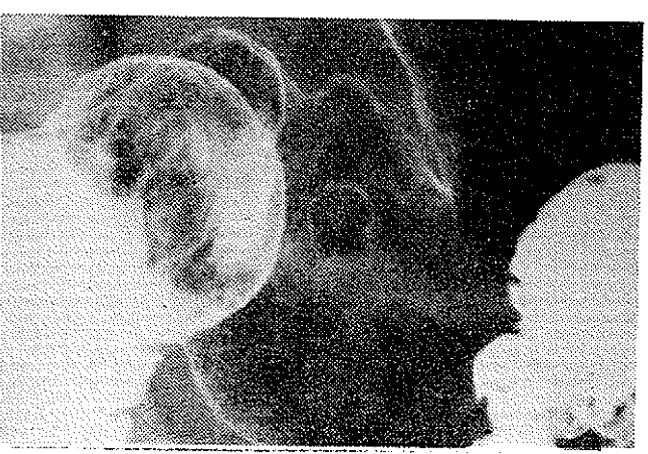

図 3 胃X線写真 : 背臥位二重造影

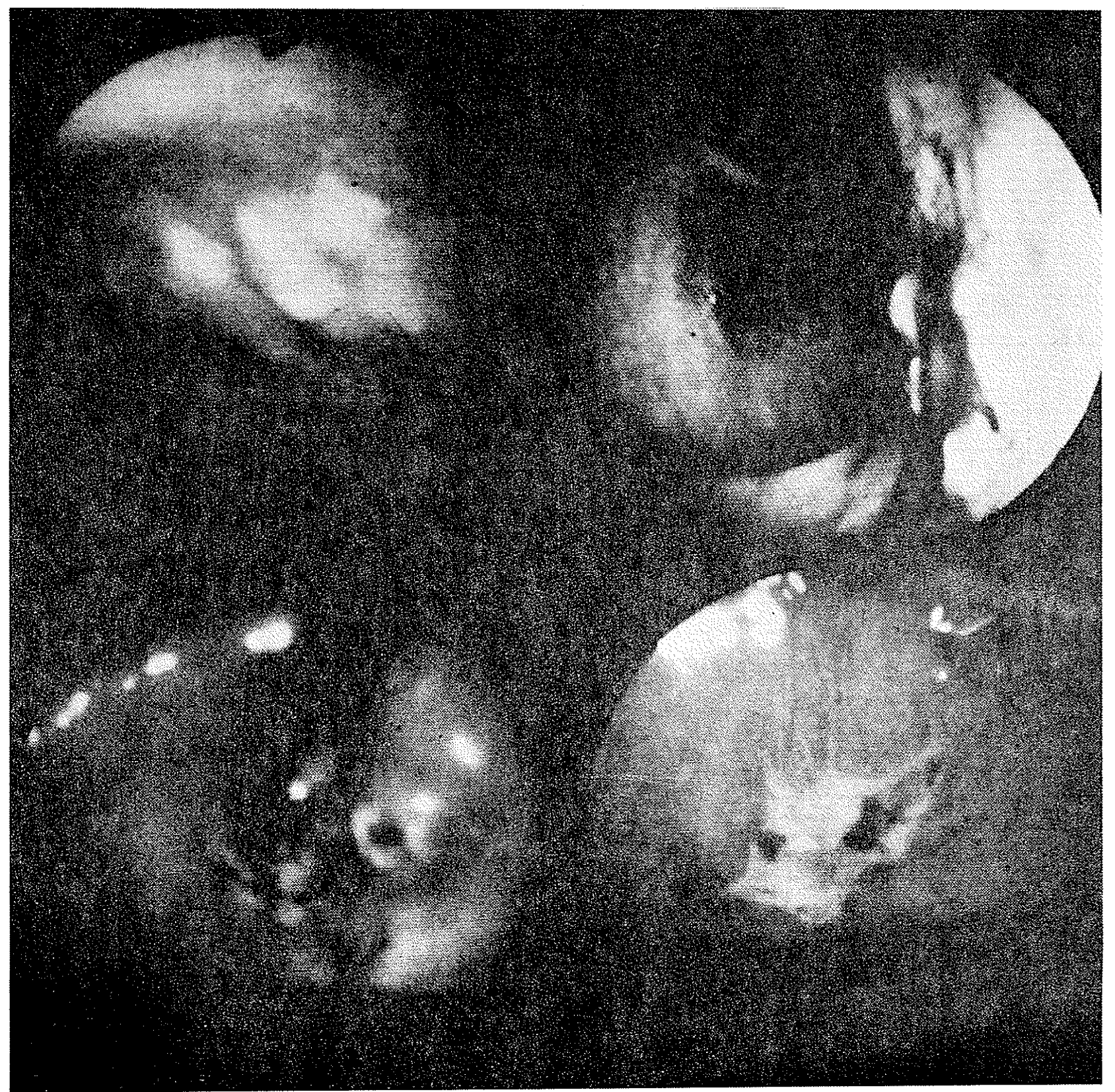

図4 \begin{tabular}{l|ll}
$\mathrm{a}$ & $\mathrm{b}$ & $\mathrm{a}:$ : レーザー照射前 \\
\hline $\mathrm{c}$ & $\mathrm{d}$ & $\mathrm{c}:$ : レーザー照射直後
\end{tabular}

b : snare polypectomy 後

$\mathrm{d}:$ レーザー照射 5 日後 


\section{$V$ 考 按}

牛肝贜実験において、蒸溜水 $(0.5 \mathrm{ml} / \mathrm{min})$ を使用 した場合には $\mathrm{CO}_{2}(400 \mathrm{ml} / \mathrm{min})$ を使用した場合に 比して凝固径が大きくなる傾向を示すが，乙れは レーザー本来の熱エネルギーによる直接的な組織 凝固と石英ファイバーと人エサファイア接合部に おいて蒝溜水の沸腾が起り，その沸腾した蒸溜水 が組織を凝固させる間接的な効果が加わったため と考えられる。又との際蒸溜水を沸騰させるに要 するエネルギーが失われるため凝固の深さは浅く なる。とのととは臨床に応用した場合穿孔という 合併症を防ぐてとができ，又粘膜の薄い大腸の病 変にも使用し得るという利点を持つ。その反面， YAGレーザーの特徵である組織浸透性が失われた 感じを持たれるかも知れないが使用する蒸溜水の 量を加減することによって凝固の深さを調節でき ないかどうかを現在検討中である。

次に内視鏡下に照射する場合，接触照射では凝 固端子を目的病変に圧迫して照射するため, 誤照 射が起りにくい。非接触照射において照射エネル ギーと効果の関係を不明瞭にしている原因として ，(1)目的病変に垂直に照射できない場合が多い。 すなわち多くは斜めからの照射となり深部への効 果は弱くなる。(2)照射距離が常に一定でないため 照射面の power densityが不明である。以上の 2 点が考えられる。(1)については接触照射の場合に もあてはまるが，接触照射では照射距倠は常に一 定であるため照射面の power densityも一定とな り非接触照射に比し照射エネルギーと効果の関係 は明瞭となる。又接触照射では照射距離がゼロと なるため照射距離によるエネルギーの賣失がなく なり低出力で効果が得られる様になる。

今回開発した凝固端子は辺縁に丸みをつけてあ るので病変に斜めから接触照射する場合, 病変の 上を凝固端子がすべり易いてとが判った。ての点 を今後の課題の一つとして,さらに基礎実験を重 被智木へ応用して行きたい。

\section{Vl 結 論}

1. 接触照射では照射エネルギーと効果の関係 がより正確になる。

2. 凝固端子の保護のために蒸溜水を使用する ことで疑固組織の付着を防止できる。

3. 低出力で十分な効果があるため将来安価な 装置が開発される可能性がある。

最後に凝固端子の開発に協力を頂いた SLT Japan の大工園氏に謝意を表します。 